\title{
POLITISASI BAHASA MELALUI EUFEMISME DALAM PROGRAM BERITA DI TELEVISI
}

\author{
Hermaliza ${ }^{1}$, Ermawati. $S^{2}$ \\ Universitas Islam Riau, Pekanbaru, Indonesia ${ }^{1,2}$ \\ hermaliza@edu.uir.ac.id ${ }^{l}$, ermawati.s@edu.uir.ac.id ${ }^{2}$
}

\begin{abstract}
This study discussed the politicization of language through euphemisms that conducted at the time of news broadcasts on television stations by noticing the background of the use of the euphemisms. Euphemism in the mass media is not merely aimed at replacing taboo words, but rather is ideological politics. The problem raised in this study was "How was the politicization of language through euphemisms in news programs on television in terms of its use?". The purpose of this study was to describe the form and function of politicizing the meaning of words through euphemisms in news programs contained on television. This research was a descriptive research. Data analysis was performed using content analysis and then explained in accordance with the research findings. Based on the results of the study, the authors found that politicized euphemisms in the TVone news program amounted to 30 euphemisms with several reasons why the euphemisms were chosen and used include: (1) to smooth out words so that other people are not offended, (2) to keep things secret, (3) for diplomacy or berororis, (4) to disguise meaning, (5) to avoid panic and fear, (6) to respect others.
\end{abstract}

Keywords: euphemisms, television news, politicization

\begin{abstract}
ABSTRAK
Kajian ini membahas mengenai politisasi bahasa melalui eufemisme yang dilakukan pada saat tayangan berita di stasiun televisi dengan memperhatikan latar belakang penggunaan eufemisme tersebut. Eufemisme dalam media massa bukan semata-mata bertujuan menggantikan kata-kata tabu, akan tetapi lebih bersifat politik ideologis. Masalah yang diajukan dalam penelitian ini adalah "Bagaimanakah politisasi bahasa melalui eufemisme dalam program berita di televisi ditinjau dari latar belakang penggunaanya?". Tujuan penelitian ini mendeskripsikan mengenai bentuk serta fungsi politisasi makna kata melalui eufemisme pada program berita yang terdapat di televisi. Penelitian yang dilakukan ini termasuk jenis penelitian deskriptif. Analisis data dilakukan dengan menggunakan analisis isi selanjutkan dipaparkan sesuai dengan temuan penelitian. Berdasarkan hasil penelitian penulis menemukan Eufemisme yang dipolitisasi dalam program berita TVone berjumlah 30 eufemisme dengan beberapa alasan mengapa eufemisme tersebut dipilih dan digunakan di antaranya: (1) eufemisme untuk menghaluskan ucapan agar orang lain tidak tersinggung, (2) eufemisme untuk merahasiakan sesuatu, (3) eufemisme untuk berdiplomasi atau beretoris, (4) eufemisme untuk menyamarkan makna, (5) eufemisme untuk menghindari kepanikan dan ketakutan, (6) eufemisme untuk menghormati orang lain.
\end{abstract}

Kata Kunci: berita televisi, eufemisme, politisasi

\section{PENDAHULUAN}

Bahasa dan kehidupan manusia merupakan dua unsur yang tidak dapat dipisahkan. Bahasa berfungsi sebagai alat komunikasi. Untuk itu manusia sebagai makhluk sosial sangat memerlukan bahasa sebagai wahana komunikasi secara lisan maupun tulisan dan sebagai alat untuk menyampaikan isi pikiran, dan mengekspresikan diri. Oleh karena itu, bahasa secara umum dapat dipahami sebagai alat komunikasi verbal yang hanya dimiliki oleh manusia (Alber dan Febria, 2018:78; Nalenan, 2019:103;104).

Senada dengan pendapat Alber, Febria, dan Nalenan, Kurniawam (2015:161) menjelaskan bahwa manusia memerlukan instrumen dalam kegiatan interaksi dengan 
sesama. Instrumen tersebut berfungsi untuk mengekspresikan diri dan mengungkapkan maksud dan tujuan interaksi. Intrumen tersebut disebut bahasa.

\begin{tabular}{lccr}
\multicolumn{2}{c}{ Kemampuan } & manusia & untuk \\
melakukan & interaksi & dengan & efektif \\
memerlukan & adanya & pemahaman & dan \\
penguasaan & kompetensi & komunikatif & baik
\end{tabular}
secara lisan maupun tulisan. Menurut Djatmika (2014:7) dalam berkomunikasi penutur bahasa memiliki berbagai kompetensi seperti kompetensi kebahasaaan, kompetensi sosiolinguistik, kompetensi tipologi, kompetensi sistem semiotik selain bahasa, kompetensi konteks situasi, dan juga konteks budaya. Semua jenis kompetensi tersebut sangat berperan dalam melakukan interaksi sosial dengan menggunakan bahasa secara efektif.

Media massa elektronik salah satunya adalah televisi. Televisi merupakan bentuk media massa paling besar dikarenakan jangkauannya kepada publik dan berperan penting dalam penyampaian informasi atau berita. Selain itu, televisi memiliki kelebihan dibanding media penyiaran lainnya, karena setiap berita bisa didengar dan dilihat. Oleh karena itu, televisi menjadi media yang sangat berpengaruh dalam penyampaian berita atau informasi kepada masyarakat. Salah satu stasiun televisi yang mempunyai pengaruh kuat dalam penyampai berita adalah TVONE, muatan program beritanya juga lebih banyak dibandingkan stasiun TV lainnya. Pada saat ini stasiun TVONE mempunyai program berita Apa Kabar Indonesia, dalam program ini selain penyampaian berita juga terdapat model informasi yang dilakukan dalam bentuk diskusi ringan membahas topik-topik teraktual yang melibatkan ahli atau narasumber tertentu serta masyarakat umum yang relevan dengan topik berita.

Dalam penyampaian berita dan diskusi pada program Apa Kabar Indonesia inilah biasanya terjadi pemanfaatan bahasa dalam bentuk tertentu agar penerima pesan memahami bahkan meyakini apa yang disampaikan oleh pemberi pesan. Contohnya dalam bidang politik bahasa bisa digunakan untuk mencapai tujuan-tujuan tertentu. Salah satu bentuk pemanfaatan bahasa untuk tujuan politik adalah berupa penggunaan Eufemisme.
Eufemisme sebagai penghalusan bahasa, sangat mendominasi dalam dialog-dialog politik dan berita di televisi. Hal ini menjadi semacam cara bagi elit politik dan media tertentu untuk mengukuhkan jabatan serta kepercayaan masyarakat terhadap suatu permasalahan. Misalnya kata korupsi, kenaikan BBM dan kelaparan menjadi samarsamar maknanya setelah dipolitisasi menjadi komersialisasi jabatan, penyesuaian harga BBM dan rawan pangan.

Kenyataan seperti inilah yang dihadapi masyarakat, pemahaman terhadap suatu permasalahan menjadi keliru. Eufemisme yang pada awalnya bermakna denotasi sesuai dengan konsep yang merujuk, dapat mengalami perubahan makna sesuai dengan kepentingan penggunanya. Eufemisme juga terbukti telah dipakai dalam pesan-pesan politik sehingga dapat menyiratkan bahwa sesungguhnya masyarakat kita takut dengan fakta sosial budayanya sendiri. Pemakaian eufemisme semacam itu sebenarnya telah jauh dari sekedar kesantunan linguistik, akan tetapi sudah sarat dengan aneka muatan politis.

Pada satu siatuasi pesan politik yang disampaikan di televisi lebih mementingkan aspek politik dibandingkan penjelasan atau informasi yang tepat kepada masyarakat. Artinya bahasa yang digunakan dalam pesan politik mengandung banyak makna sehingga menimbulkan kekeliruan makna dan pesan yang diperoleh masyarakat adalah bukan makna sebenarnya. Dampaknya menimbulkan kebingungan dan krisis kepercayaan kepada pemerintah dan elit politik. Rahardi (2003:34) mengemukakan bahwa bahasa Indonesia telah dieksplotasi sedemikian rupa demi tujuan politik dan kekuasaan. Pemakaian tersebut tampak dominan sekali dalam fakta akronimisasi dan bentuk eufemisme terhadap istilah-istilah politik yang berlebihan.

Pemakaian bahasa untuk kepentingan politik, inilah yang disebut proses politisasi bahasa dengan menyelipkan ideologi-ideologi tertentu melalui eufemisme yang digunakan. Jadi jelas eufemisme dalam media massa bukan semata-mata bertujuan menggantikan kata-kata tabu, akan tetapi lebih bersifat politik ideologis. Berdasarkan kenyataan inilah peneliti tertarik untuk melakukan penelitian secara mendalam pada program berita Apa 
Kabar Indonesia di TVONE, mengingat peran penting eufemisme adalah untuk menyembunyi realitas dan ideologi tertentu. Adapun yang menjadi fokus dalam penelitian ini adalah politisasi bahasa melalui eufemisme ditinjau dari latar belakang penggunaanya.

Eufemisme ialah ungkapan yang lebih halus sebagai pengganti ungkapan yang dirasakan kasar, yang dianggap merugikan atau yang tidak menyenangkan. Misalnya meninggal, tunakarya. Namun eufemisme dapat juga dengan mudah melemahkan kekuatan diksi karangan. Misalnya, penyesuaian harga, kekurangan pangan, membebastugaskan.

Djajasudarma

mengemukakan bahwa eufemisme adalah ungkapan yang lebih halus sebagai pengganti ungkapan yang dirasakan kasar, yang dianggap merugikan atau yang tidak menyenangkan. Eufemisme merupakan acuan yang berupa ungkapan yang tidak menyinggung perasaan atau ungkapan halus untuk menggantikan acuan yang dirasakan menghina atau tidak menyenangkan. Intinya, mempergunakan katakata dengan arti baik atau dengan tujuan baik. Eufemisme juga ada yang mengartikan sebagai ungkapan yang tidak berterus terang

Sementara itu, Keraf (2010:132) mengatakan bahwa eufemisme adalah semacam acuan berupa ungkapan-ungkapan yang halus untuk menggantikan acuan-acuan yang mungkin dirasakan menghina, menyinggung perasaan atau mensugestikan sesuatu yang tidak menyenangkan. Lebih lanjut Pranowo (2009:22) mengatakan eufemisme merupakan salah satu jenis gaya bahasa perbandingan yang membandingkan dua hal dengan menggunakan pembanding yang lebih halus. Dalam hal ini apa yang dituturkan oleh penutur tidak menyinggung perasaan mitra tutur, atau ungkapan-ungkapan yang dapat dipersepsi menghina, menyinggung perasaan atau mensugesti sesuatu yang tidak menyenangkan bagi mitra tutur.

Wijana dan Rohmadi (2017:88-92) mengemukan bahwa eufemisme memiliki beberapa manfaat:

1. Eufemisme sebagai alat untuk menghaluskan ucapan.

Eufemisme sebagai alat untuk menghaluskan ucapan merupakan fungsi eufemisme yang paling umum. Katakata yang memiliki denotata yang tidak senonoh, tidak menyenangkan atau mengerikan, berkonotasi rendah atau tidak terhormat sdt. harus diganti atau diungkapkan dengan cara-cara tidak langsung guna menghindari berbagai hambatan atau konflik sosial.

2. Eufemisme sebagai alat untuk merahasiakan sesuatu.

Eufemisme memiliki manfaat salah satunya dalam bidang kedokteran, yaitu untuk merahasiakan sesuatu, misalnya penyakit-penyakit yang akan menimbulkan sesuatu yang mengkhawatirkan bagi orang yang mendengarnya, atau orang yang menderitanya sehingga memungkinkan timbulnya keadaan yang buruk.

3. Sebagai alat untuk berdiplomasi. Seorang pemimpin biasanya akan selalu mengemas ucapannya dengan bentukbentuk eufemisme dengan tujuan untuk sekedar beretorika dan mengendalikan situasi.

4. Sebagai alat pendidikan.

Penghalusan ucapan pada dasarnya memiliki makna edukatif. Anak sejak dini sudah diajarkan cara-cara menghindari penyebutan secara langsung kata-kata yang memiliki nilai rasa kurang sopan.

5. Sebagai alat penolak bahaya.

Pemakaian eufemisme sebagai salah satu cerminan usaha manusia untuk memperoleh ketentraman, keselamatan, dan kesejahteraan. Misalnya dalam bahasa Melayu, kata harimau dan ular diganti dengan nenek dan akar oleh orang-orang yang sedang berjalan di hutan agar memperoleh keselamatan.

Pendapat senada lainnya berasal dari Zollner (1997:92) beberapa alasan mengapa eufemisme digunakan yaitu: (a) menghindarikata atau hal-hal yang tabu, (b) untuk menutup rasa malu (c) untuk menghindari penggunaan kata-kata yang dapat menimbulkan bahaya, (d) untuk menunjukkan bahwa penutur adalah orang berpendidikan (e) karena alasan yang berkaitan dengan agama dan kepercayaan, (f) untuk menghindari penggunaan kata-kata yang kurang bagus, (g) untuk tujuan-tujuan retoris. 


\section{METODOLOGI PENELITIAN}

Penelitian ini adalah penelitian kepustakaan (library research) sehingga tempat penelitian adalah meja dan ruang kerja peneliti. Waktu penelitian lebih kurang enam bulan dari perencanaan sampai dengan selesai yakni Februari-Juli 2019. Pengumpulan data dilakukan dengan metode deskriptif dan analisis konten yakni dengan cara mengumpulkan dan memilah-milah kata atau frase yang mengandung Eufemisme yang menjadi objek penelitian. Kemudian, kata atau frase yang mengandung eufemisme tersebutlah yang akan menjadi sampel penelitian.

Penelitian ini menggunakan metode analisis isi (content analysis). Menurut Krippendorff dalam Alber dkk (2018:2) analisis isi adalah suatu teknik penelitian untuk membuat inferensi-inferensi yang dapat ditiru (replicable) dan sahih data dengan memperhatikan konteknya. Penggunaan metode analisis isi (content analysis) ini karena penelitian yang dilaksanakan bukan sekedar memaparkan data sesuai realita atau temuan saja, tetapi juga melihat data berdasarkan gejala simboliknya seperti konteks. Dengan menggunakan metode ini peneliti dapat menggambarkan penggunaan eufemisme secara rinci sehingga politisasi maknanya dapat dipahami. Adapun langkahlangkah dalam proses analisis data yaitu: Mengelompokkan data ke dalam tabel yang disediakan, mengklasifikasi data yang telah diperoleh sesuai dengan pertanyaan penelitian, menginterpretasi data berdasarkan bentuk, fungsi, dan makna, selanjutnya, merumuskan dan menyimpulkan hasil penelitian yang diperoleh.

\section{HASIL DAN PEMBAHASAN}

Data yang sudah diperoleh dianalisis merujuk kepada sejumlah teori yang sudah ditentukan. Pada bagian ini, penulis mengelompokkan data tersebut dalam paparan berikut ini:

\section{Eufemisme sebagai alat untuk menghaluskan ucapan agar tidak menyinggung orang lain.}

Data 1:
Mungkin ada oknum-oknum tertentu yang membuat atau memanipulasi sehingga mencemarkan partai-partai yang ada (Apa kabar Indonesia Malam, 11/04/2019)

Eufemisme manipulasi bermakna terjadinya penggelapan atau penyelewengan. Dari konteks berita penggelapan atau penyelewengan yang dimaksud adalah terkait pelaksanaan pemilu di Selangor Malaysia, sebagian surat suara sudah dicoblos pasangan calon yang sengaja dicoblos adalah pasangan nomor urut 01. Hal tersebut tentu saja memberikan kesan negatif bagi pasangan atau tim 01, walaupun KPU pusat belum bisa memastikan kebenaran kejadian tersebut, akan tetapi berita-berita terkait kertas suara yang tercoblos sudah menyebar ke dalam negeri. Data (1) pada eufemisme manipulasi merupakan politisasi bahasa dengan tujuan menghaluskan ucapan agar lawan bicara atau orang yang mendengarkan tidak tersinggung serta tidak merasa malu. Ucapan tersebut digunakan agar pernyataan tidak menyinggung pemerintah khususnya penyelengara pemilu setempat dan pasangan 01. Pernyataan tersebut disampaikan oleh saksi pasangan 02 yang dimintai keterangan oleh pihak TVone. Berdasarkan konteks berita dapat dipahami bahwa alasan penggunaan eufemisme tersebut semata-mata hanya untuk menghaluskan ucapan agar layak disampaikan dan didengar oleh banyak orang.

Data 2:

Kita sudah mencium bau kecurangan, dari pihak kami khususnya 02, tersusun rapi oleh unsur-unsur relawan dengan kesungguhan dan pandainya menemukan kecurangan. (Apa kabar Indonesia Malam, 11/04/2019)

Selain itu, hal yang sama juga terjadi pada contoh (2) yaitu eufemisme mencium bau kecurangan. Makna dari eufemisme tersebut adalah adanya kecurangan dalam pelaksanaan pemilu, dari pantauan pihak BPN 02 memang telah terjadi kecurangan dalam pelaksanaan pemilu. Hal ini diketahui dari keterangan saksi 02 yang menyebutkan bahwa relawan dari pasangan calon nomor urut 02 sudah 
melakukan observasi terkait kecurangan yang terjadi di Selangor Malaysia. Akan tetapi temuan ini hanya ditegaskan oleh pihak BPN (badan pemenangan nasional) saja, bahkan KPU pusat belum bisa memastikan kejadian tersebut. Eufemisme tersebut digunakan dengan tujuan menghaluskan ucapan agar tidak ada pihak yang tersinggung.

Data 3:

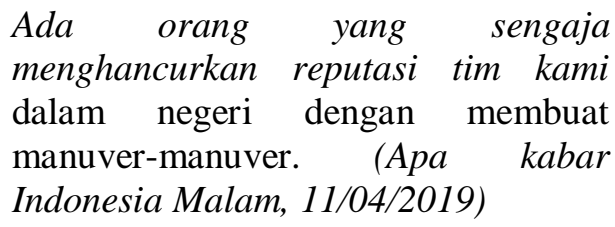

Dalam program berita dengan tema yang sama juga dihadiri oleh narasumber dari partai Nasdem sebagai salah satu partai pendukung pasangan 01 yaitu Putu Arya. Dalam komentarnya juga terdapat penggunaan eufemisme yaitu (3) ada orang yang sengaja menghancurkan reputasi tim kami yang bermakna pihak lawan politik yaitu pendukung pasangan capres cawapres 02 dianggap sebagai pelaku pencoblosan kertas suaraoleh narasumber. Makna tersebut diketahui dari konteks pembicaraan dalam berita tersebut, bahwa sebelumnya terjadi pertentangan opini antara Putu Arya dengan Prio Budi Priyono sebagai tim BPN 02. Eufemisme tersebut digunakan untuk memperhalus ucapan agar lawan bicaranya tidak merasa tersinggung, apalagi kasus ini belum terbukti pelakunya sehingga membuat pembicara merasa takut jika mengatakan hal sebenarnya karena akan terkesan menuduh pihak lawan politik.

Data 4:

Perbedaan pilihan dalam pemilu kali ini nampaknya banyaknya kasus persekusi yang muncul (Apa kabar Indonesia Malam, 5 April 2019).

Penggunaan eufemisme (4) persekusi digunakan oleh pembawa acara dengan Tema Persekusi, robohnya demokrasi kami. Kata persekusi bermakna penganiayaan, dalam konteks tersebut yang dibicarakan adalah berbagai kasus penganiayaan yang terjadi di berbagai daerah menjelang pemilu, termasuk yang terjadi pada tokoh politik atau masyarakat yang berbeda pilihan politiknya. Kata persekusi inipun muncul atau banyak digunakan media untuk memberitakan berbagai kasus penganiayaan tersebut. Jelas penggunaan kata persekusi untuk menghalus makna dari kata tersebut, kata persekusi dipolitisasi oleh media, tokoh politik untuk kepentingan masing-masing seperti untuk menyindir, menyinggung bahkkan memojokkan seseorang atau sekelompok orang yang dianggap sebagai lawan poltikinya.

Data 5:

Sebelumnya awal Maret lalu Neno Warisman dan Roky Gerung kembali mendapatkan intimidasi saat akan memberikan sosialisasi capres melalui media dakwah dan diskusi publik. (Apa kabar Indonesia Malam, 5 April 2019).

Masih dalam tema berita yang sama yaitu persekusi, robohnya demokrasi kami, terdapat eufemisme intimidasi digunakan oleh pihak TVone untuk menyatakan telah terjadi ancaman terhadap Neno Warisman dan Roky Gerung dalam kampanye sosialisasi capres dan cawapres. Eufemisme (5) intimidasi dalam konteks ini digunakan untuk menggantikan kata ancaman bermakna lebih kasar, sehingga dipilihlah kata intimidasi untuk menjaga dan mengendalikan reaksi politik dari kedua belah pihak capres dan cawapres. Eufemisme intimidasi dipolitisasi oleh pihak TVone dalam berita tersebut.

Data 6:

Kampanye pasangan capres dan cawapres Prabowo dan Sandiaga Uno di GBK diwarnai polemik (Laporan Utama, 9 April 2010).

Polemik bermakna perdebatan, dalam konteks berita data (6) yang menjadi perdebatan adalah kampanye pasangan calon 02 yaitu prabowo dan Sandiaga Uno di GBK tentang politik identitas, yang dikhawatirkan akan menimbulkan perpecahan bangsa. Kekhawatiran tersebut berawal dari reaksi ketua umum partai Demokrat SBY tentang isi pidato tersebut. Kata polemik memang kerap digunakan dalam program berita di televisi 
untuk menggantikan kata perdebatan yang dinilai berkonotasi negatif.

Data 7:

Mengapa diujung masa kampanye Demokrat justru menyentil model kampanye capres cawapres (Laporan Utama, 9 April 2010).

Berkaitan dengan isi pidato pasangan calon 02 yaitu prabowo dan Sandiaga Uno di GBK tentang politik identitas, reaksi dari ketua umum partai Demokrat tersebut yang disebut sebagai eufemisme (7) menyentil. Kata menyentil dalam konteks berita tersebut bermakna memarahi, hal ini dapat diketahui dari uraian berita yang menyebutkan ketua umum partai Demokrat resah dengan isi pidato tersebut sehingga berinisiatif menulis pemberitahuan melalui surat.

Data 8:

Meski Saran SBY sudah diakomodasi oleh Pasangan capres cawapres Prabowo Sandiaga Uno himbauan ketua umum Partai Demokrat dinilai sudah terlambat. (Laporan Utama kabar petang, 9 April 2010)

Politisasi eufemisme pada data (8) yaitu sudah terlambat bermakna tidak tidak ada gunanya. Pernyataan tersebut disampaikan oleh pengamat politik berkaitan pernyataan dan reaksi SBY terhadap kampanye Prabowo Sandi. Beliau menilai kritikan SBY tersebut sudah tidak berguna lagi, karena pidato tersebut sudah terlanjur disampaikan saat kampanye.

Data 9:

Adanya rencana-rencana mobilisasi massa setelah pencoblosan itu, kan ada quick count, ada perhitungan cepat yang dilakukan lewat medsos atau media lainnya (Apa Kabar Indonesia Petang, 16 April 2019).

Pernyataan tersebut disampaikan oleh Menkopolhukam, dengan menggunakan eufemisme (9) mobilisasi massa terkesan lebih halus dibandingkan kata yang dipilih adalah pengerahan massa, karena ini akan berdampak kepada kekhawatiran masyarakat menjelang pemilihan umum tanggal 17 April 2019. Menkopulhukam mengerahkan ribuan aparat gabungan TNI-Polri untuk mengamankan sejumlah TPS di berbagai daerah.

Data 10:

Ada rawan kumpulan-kumpulan massa yang bisa memberikan tekanantekanan secara psikologis, misalnya warga minoritas, tempat yang mudah untuk diprovokasi, daerah yang padat penduduk (Apa Kabar Indonesia Petang, 16 April 2019)

Eufemisme (10) diprovokasi bermakna dihasut, sesuai konteks berita pernyataan tersebut diarahkan kepada individu atau sekelompok orang yang mudah dihasut oleh pihak tertentu menjelang pemilu. Kata provokasi digunakan karena memiliki nilai rasa lebih baik jika dibandingkan dengan kata dihasut. Politisasi dengan memanfaatkan bentuk eufemisme ini gencar dilakukan oleh aparat maupun media massa khususnya televisi.

\section{Eufemisme sebagai alat untuk merahasiakan sesuatu}

Data 11:

Temuan-temuan permasalahan secara teknis penyelenggaraan maupun yang menyangkut keamanan sudah bisa diatasi melalui koordinasi ketat pusat dan daerah (Apa Kabar Indonesia Petang, 16 April 2019).

Pada eufemisme (11) sudah bisa diatasi bermakna sudah ditindak pemerintah, pernyataan Menkopolhukam tersebut dilatarbelakangi alasan untuk merahasiakan sesuatu. Eufemisme tersebut dapat membatasi pandangan masyarakat dalam memahami kinerja pemerintah, jika eufemisme tidak dipolitisasi sedemikian rupa akan menimbulkan reaksi negatif dari masyarakat terhadap pemerintah, untuk menjaga itu semua aparat pemerintah kerapkali memilih kosa kata untuk merahasiakan sesuatu atau merahasiakan kenyataan yang sebenarnya terjadi.

Data 12:

Politisasi Bahasa Melalui Eufemisme dalam Program Berita di Televisi 
Tokoh-tokoh kita sinyalir, ucapannya sudah kita dengarkan, kita sisir, analisis itu sudah ada. (8 Mei 2019).

Pernyataan Menkopolhukam terkait akun di media sosial yang akan ditutup, mengamati setiap ucapan tokoh politik maupun masyarakat yang mengandung ujaran kebencian, pada data (12) tersebut beliau menegaskan sudah ada tokoh politik yang mereka tandai dan cermati tulisannya di media sosial yang dianggap bisa mempengaruhi masyarakat khususnya penggunaan media sosial, eufemisme disinyalir tersebut bukanlah bermakna sekedar mencari tau, tetapi sudah ada data yang mereka miliki untuk melaporkan tokoh politik dan membawa ke ranah hukum. Jelas sekali dalam pernyataan tersebut Wiranto menyembunyi kenyataan yang sebenarnya. Inilah yang disebut sebagai politisasi bahasa, menggunakan bahasa tertentu untuk tujuan tertentu pula, bisa jadi memasukkan ideologi atau unsur kekuasaan di dalamnya.

\section{Eufemisme sebagai alat untuk berdiplomasi atau bertujuan retoris}

Data 13:

Kita banyak melihat ekspose dari akun yang menyebarkan kebencian, oleh sebab itu harus ditake down (8 Mei 2019).

Analisis data (13) merupakan penggunaan eufemisme untuk data berdiplomasi atau bertujuan retoris semata, pernyataan Wiranto sebagai seorang pemimpin dalam ucapannya memanfaatkan bentuk eufemisme dengan menggunakan bahasa asing yaitu ditake down. Makna dari eufemisme take down adalah mematikan dan menutup akunakun di media sosial yang dianggap meresahkan dan menghasut masyarakat serta dinilai melanggar hukum. Dari pernyataan Wiranto tersebut, beliau menegaskan akan menindak tegas pelaku-pelaku penghasut atau ujaran kebencian, Pernyataan beliau tersebut berkaitan dengan situasi politik menjelang pemilihan presiden dan wakil presiden, untuk menghindari tersebarnya ujaran dan ajakan dari berbagai akun media sosial. Dalam pemilihan bentuk eufemisme tersebut terjadilah politisasi bahasa untuk kepentingan menertibkan kondisi politik menjelang pemilu.

Data 14:

Para ahli hukum kita kumpulkan, mari kita dengarkan (Kabar Petang, $8 \mathrm{Mei}$ 2019)

Data 15:

Ini pun kita bentuk hanya sebagai tim asistensi untuk membantu kantor polhukam untuk menyisir hal-hal mana yang kita peringatkan atau diberi sanksi. (Kabar Petang, 8 Mei 2019).

Selanjutnya pada data no (14) dan (15) terdapat eufemisme pada kata kita dengarkan dan menyisir. Makna eufemisme kita dengarkan tersebut adalah melakukan analisis terhadap akun-akun di media sosial yang dianggap menyebarkan ujaran kebencian. Jadi bukanlah bermakna sesuai bentukan katanya, hal ini diketahui melalui konteks beritanya. Pada eufemisme menyisir bermakna memantau akun-akun di media sosial yang sudah ditandai oleh Tim asistensi yang sudah dibentuk oleh Menkopulhukam khusus menjelang pemilihan umum ini. dengan menggunakan kedua kata yang bermakna tidak langsung tersebut, Wiranto ingin menegaskan bahwa beliau sebagai pemimpin bukanlah membatasi kebebasan berpendapat khususnya untuk penggunaan media sosial, akan ettapi ingin membrikan kesan bahwa beliau adalah pemimpin yang bijaksana. Kedua eufemisme ini kita dengarkan dan menyisir dipoltisasi sedemikian rupa untuk beretorika dan berdiplomasi.

Data 16:

Menurut JK usai pemilu pertemuan antara Jokowi dan Prabowo cepat terlaksana sebagai bentuk rekonsiliasi (Apa Kabar Indonesia Malam, 25 April 2019).

Eufemisme rekonsiliasi pada data (16) tersebut bermakna melakukan komunikasi dengan tujuan memulihkan hubungan atau memperbaiki hubungan. Dalam konteks ini yang dimaksud adalah Capres Jokowi dan Prabowo. Penggunaan kata rekonsiliasi ini juga menjadi suatu istilah yang kerap dipakai berkaitan dengan pemilu, banyak tokoh politik 
bahkan media yang memanfaatkan kata ini untuk sekedar beretorika dan berdiplomasi demi kepentingan politik.

Data 17:

Tim nasional dari Jokowi-Makruf amin menegaskan tidak ada intervensi dari pemerintah (Kabar petang, 15 Maret 2019).

Politisasi dengan memanfaatkan eufemisme (17) intervensi bukan suatu istilah baru dalam bidang politik, kata ini cukup populer digunakan di lingkungan masyarakat maupun media massa, khususnya yang memberitakan terkait wewenang pemerintah terhadap suatu permasalahan. Dalam kutipan data tersebut intervensi yang dimaksud bermakna campur tangan Jokowi dalam kasus korupsi yang melibatkan Romahurmuziy dengan memanfaatkan kekuasaannya sebagai presiden.

\section{Eufemisme untuk menyamarkan makna}

Data 18:

Pengamanan ketat ini dilakukan untuk antisipasi terjadinya gesekan sehingga bisa menghambat proses pemungutan suara ulang (Apa kabar Indonesia Malam, April 2019).

Pernyataan dari TvOne dalam penyampaian berita terkait pemungutan suara ulang di Makassar terdapat contoh eufemisme yaitu (18) Terjadinya gesekan dan (19) kurang diminati warga. Penggunaan eufemisme tersebut dengan tujuan menyamarkan makna misalnya pada data (18) bermakna menghindari terjadinya kerusuhan, kata kerusuhan tersebut dapat memiliki persamaan makna dengan kata kericuhan dan kekacauan, ketiganya memiliki konotasi makna yang negatif jika salah satunya digunakan tentu saja akan memberikan kesan negatif pada proses pemilihan ulang yang dilakukan oleh pemerintah setempat. Oleh sebeb itu, penggunaan frasa terjadinya gesekan dengan tujuan untuk menyamarkan makna.

Data 19:
Di TPS 08 Pandang, Makassar kurang diminati warga dari 271 DPT hanya 71 yang memilih coblos ulang (Apa kabar Indonesia Malam, April 2019.

Sedangkan pada contoh (19) bermakna banyak warga yang tidak ikut serta dalam kegiatan pemungutan suara ulang, yaitu dari 271 DPT hanya 71 yang berpartisipasi. Dilihat dari kenyataan yang ada tentu ini bukan lagi bermakna kurang diminati, tetapi memang warga tidak mau ikut serta dalam pemilu ulang. Sama halnya dengan data sebelumnya, eufemisme kurang diminati untuk menyamarkan makna yang sebenarnya dari suatu kejadian. Eufemisme dipolitisasi oleh TVone dalam program beritanya sehingga makna dari suatu kata menjadi kabur dan makna yang sebenarnya menjadi samar.

Data 20:

Tadi pagi Tim KPK mengamankan 5 orang, setelah diduga terjadi interaksi yang kesekian kalinya. (Laporan Utama, kabar petang, 15 Maret 2019).

Eufemisme (20) mengamankan maknanya adalah menangkap. Pernyataan tersebut disampaikan oleh Juru bicara KPK, bahwa pihaknya sudah menangkap 5 orang yang diindentifikasi terlibat kasus suap, salah satunya adalah Romahurmuziy ketua umum partai PBB. Kata mengamankan dipolitisasi sehingga makna yang sebenarnya menjadi samar atau tidak jelas. Masyarakat bisa saja berasumsi bahwa pihak yang terlibat korupsi hanya dimintai keterangan atau yang lainnya. Media massa baik cetak maupun elektronik sering sekali menggunakan eufemisme mengamankan untuk menggantikan kata menangkap yang dinilai memiliki makna yang lebih negatif. Tentu saja pemilihan eufemisme ini pada umumnya di media massa sarat akan muatan kekuasaan dan ideologis.

\section{Eufemisme untuk menghindari kepanikan dan ketakutan}

Data 21:

Menjelang pengumuman hasil akhir pemilu oleh KPU, suhu panas seakan 
belum mereda (Laporan Utama Kabar

Petang, 14 Mei 2019)

Data (21) suhu panas merupakan bentuk eufemisme untuk menghindari kepanikan. Politisasi bahasa dengan bentuk eufemisme suhu panas bermakna adanya ketegangan situasi. Ketegangan yang dimaksud adalah kondisi politik menjelang pengumuman hasil akhir pemilu. Hal ini dikarenakan adanya isi pengerahan massa atau people power jika hasil akhir pemilu tidak sesuai harapan. Penggunaan eufemisme ini semata-mata untuk meredam kondisi politik agar tidak menimbulkan kepanikan bagi penerima berita.

Data 22:

Polisi terus memburu pelaku makar siapa saja yang diduga dalam kasus makar, sejumlah tokoh diperiksa dan ditetapkan sebagai tersangka. (Kabar Petang, 29 Mei 2019.

Pada tajuk berita terjerat makar di tahun politik, pilihan kata makar merupakan eufemisme yang bertujuan untuk menghindari kepanikan atau ketakukan karena bisa saja pihak kepolisian dan Tvone menggunakan kata kudeta yang memiliki makna lebih menakutkan yaitu penggulingan pemerintahan yang sah dengan cara kekerasan. Jadi jelas penggunaan kata makar pada dasarnya untuk meredakan suasana politik menjelang pengumuman akhir hasil pemilu.

\section{Eufemisme untuk menghormati orang lain}

Data 23:

Muncul spekulasi demokrat memainkan politik dua kaki (Laporan Utama Kabar Petang, 5 Maret 2019).

Eufemisme dalam bentuk kiasan digunakan ditujukan kepada partai demokrat, yang dalam konteks ini memberikan dukungan untuk kedua calon presiden dan calon wakil presiden. Hal tersebut menjadi perbincangan banyak pihak setelah AHY berpidato tentang pesan-pesan kepada presiden yang nantinya terpilih. Sikap partai demokrat inilah yang dinilai banyak pihak tidak memiliki pendirian, selalu berada di tengah-tengah dalam bidang politik.

Data 24:

Dimata kubu oposisi aksi capres petahana tersebut dianggap pencitraaan belaka. (Laporan Utama Kabar Petang, 13 Maret 2019)

Eufemisme pencitraan sangat sering kita dengar terutama tertuju kepada presiden Jokowi yang selama ini selalu memanfaatkan politik pencitraan, yaitu memperlihat kepada masyarakat bahwa beliau memiliki sifat yang merakyat, peduli orang kecil dan tidak segansegan bergabung dengan rakyat. Akan tetapi kata pencitraan itu sendiri menjadi berkonotasi negatif oleh sebagai orang, karena apa ditampilkan sebenarnya belum tentu yang sebenarnya. Misalnya saja banyak janji-janji kampanye yang belum direalisasikan sehingga tingkat kepercayaan masyarakat terhadap apa yang dicitrakan menjadi berkurang.

\section{Data 25:}

Tudingan balik dilemparkan ke kubu 02 , kubu petahana menyebut aksi buka baju yang dilakukan prabowo menjadi bukti bahwa capres penantang hanya bisa buat aksi tanpa makna (laporan utama kabar petang, 13 Maret 2019).

Perdebatan opini kedua kubu pasangan capres dan cawapres terkait gaya kampanye dari keduanya. Ada yang menilai gaya kampanye Jokowi lebih bermanfaat bagi rakyat, ada pula pihak yang mengklaim gaya kampanye Prabowo terkesan apa adanya jauh dari pencitraan. Dari kutipan tersebut terdapat eufemisme aksi tanpa makna tertuju pada aksi Prabowo membuka baju dan melemparkannya di kerumunan massa pada saat kampanye. Hal inilah yang dipandang oleh pihak lawan yaitu Tim Jokowi sebagai suatu perbuatan yang tidak berguna atau tidak bermanfaat sama sekali bagi masyarakat. Penggunaan eufemisme tersebut semata-mata hanya untuk menghormati orang lain.

Data 26:

Rakyat bisa menilai mana yang orisinil dan mana yang hanya kampanye 
belaka (laporan utama kabar petang, 13 Maret 2019).

Data 27:

Sebaliknya pasangan petahana lagilagi disebut selalu mengandalkan adegan rekayasa. (laporan utama kabar petang, 13 Maret 2019).

Eufemisme hanya kampanye belaka ditujukan kepada Prabowo dari tajuk berita adu gaya kampanye capres. Pihak Jokowi menilai kampanye Jokowi jauh lebih bermanfaat dibandingkan Prabowo, bahkan dinilai lebih orisinil. Dari tanggapan tersebut dapat diketahui makna yang pernyataan hanya kampanye belaka yang sesungguhnya ingin diucapkan adalah kata palsu sebagai lawan dari kata orisinil atau asli. Sementara pada eufemisme rekayasa dalam tajuk berita yang sama bermakna kebohongan, pernyataan tersebut ditujukan kepada Jokowi yang dianggap apa yang disampaikan saat kampanye hanya kebohongan belaka.

\section{Data 28:}

...tetapi malah memainkan gimmickgimmick politik yang tidak menguntungkan rakyat (laporan utama kabar petang, 13 Maret 2019).

Gaya kampanye kedua pasangan calon presiden dianggap oleh pengamat politik sebagai suatu gimmick-gimmick politik semata, sebatas mencari perhatian masyarakat dengan hal-hal yang tidak bermanfaat sama sekali bagi pendukungnya masing-masing. Eufemisme gimmick-gimmick digunakan untuk menggantikan kata tipu muslihat yang memiliki makna lebih kasar dan negatif dibanding kata gimmick.

Data 29:

Di tengah rumor demokrat bermain dua kaki, Sandi yakin partai besutan SBY jelas mendukung Prabowo Sandi (laporan utama kabar petang, 13 Maret 2019).

Politisasi bahasa dengan eufemisme rumor terdapat dalam kutipan berita (29), pernyataan tersebut disampaikan TVone dalam tajuk berita Pidato AHY dukung siapa?
Menyikapi pidato AHY yang seolah-olah mendukung Jokowi, padahal jelas sebelumnya partai Demokrat merupakan salah satu partai yang mendukung pasangan calon Prabowo Sandi. Perubahan partai Demokrat inilah yang disebut banyak pihak sebagai rumor yang dasarnya bermakna gunjingan, artinya sesutau yang belum jelas kebenarannya. Jika kata gunjingan yang dipilih tentu ini akan memberikan kesan negatif atau rendahan, dengan kata rumor pernyataan lebih bermakna halus dan terdengar lebih elegan dalam bidang politik.

Data 30:

Dewan malas laporkan kekayaannya (Kabar Petang, 6 April 2019).

Kata malas dalam kutipan berita tersebut untuk mengantikan kata tidak patuh. Sejumlah anggota dewan enggan melaporkan harga kekayaannya kepada KPK. Dalam konteks berita tersebut kata malas memberikan kesan bahwa anggota dewan tidak punya kesungguhan atau karena kesibukannya dalam pekerjaan tidak memiliki waktu untuk melaporkan hartanya kepada KPK. Sementara jika kata tidak patuh yang digunakan akan memberikan kesan bahwa anggota depan sudah melanggar aturan yang sudah ditetapkan KPK. Dalam hal ini kata malam dianggap oelh pihak TVone memiliki makna yang lebih baik disbanding kata tidak patuh.

\section{SIMPULAN}

Berdasarkan analisis data, terkait politisasi bahasa melalui eufemisme dalam program berita di TVOne dapat disimpulkan bahwa berbagai pertimbangan dilakukan oleh pihak TVone dalam mengutip, menampilkan pernyataan seseorang atau bahkan menampilkan sosok untuk dijadikan acuan atau sumber dalam pemberitaan. Berbagai pemberitaan Tentu saja ini tidak lepas dari unsur kekuasaan dan ideologi di dalamnya. Eufemisme yang dipolitisasi dalam program berita TVone berjumlah 30 eufemisme dengan beberapa alasan mengapa eufemisme tersebut dipilih dan digunakan di antaranya: (1) eufemisme untuk menghaluskan ucapan agar orang lain tidak tersinggung, (2) eufemisme untuk merahasiakan sesuatu, (3) eufemisme 
untuk berdiplomasi atau beretoris, (4) eufemisme untuk menyamarkan makna, (5) eufemisme untuk menghindari kepanikan dan ketakutan, (6) eufemisme untuk menghormati orang lain. Dari keenam jenis alasan tersebut eufemisme untuk menghaluskan ucapan sebagai bentuk menjaga perasaan lawan bicara ditemukan lebih banyak, disusul eufemisme untuk menghormati orang lain dengan tujuan menjaga situasi politik baik dari tokoh politik yang pernyataannya dikutip dan dinarasikan kembali oleh TVone maupun pernyataan pihak dari TVone itu sendiri.

\section{REFERENSI}

Alber, A., \& Febria, R. (2018). Analisis Kesalahan Berbahasa Tataran Sintaksis dalam Kumpulan Makalah Mahasiswa Universitas Islam Riau. GERAM, 6(2). https://doi.org/https://doi.org/10.25299/g eram.2018.vol6(2).2143

Alber, A. dkk. (2018). Analisis Kesalahan Berbahasa dalam Tajuk Rencana Surat Kabar Kompas. GERAM, 6(1). https://doi.org/https://doi.org/10.25299/g eram.2018.vol6(1).1218

Djajasudarma, F. (1993). Metode Linguistik. Bandung: Refika Aditama.

Djatmika. (2014). Pernik Kajian Wacana. Yogyakarta: Graha Ilmu.

Keraf, G. (2010). Diksi dan Gaya bahasa. Jakarta: Gramedia Pustaka Utama.

Kurniawam, H. (2015). Gramatikalisasi dalam Petunjuk Perlatihan Buku Teks Bahasa Indonesia SMA Kelas X. Jurnal Pena Indonesia Jurnal Bahasa Dan Sastra Indonesia Serta Pengajarannya, 1(2), 42-58.

https://doi.org/http://dx.doi.org/10.26740/ jpi.v1n2.p163-195

Nalenan, J. S. (2019). Bentuk Bahasa Kasual Guyub Tutur di Wilayah Perumahan BTN Kefamenanu. JUBINDO, 4(1). Retrieved from http://jurnal.unimor.ac.id/JBI/article/view /202/196

Pranowo. (2009). Berbahasa Secara Santun. Yogyakarta: Pustaka Pelajar.

Rahardi, K. (2003). Bahasa Indonesia dalam Problematika Kekinian. Yogyakarta: Dioma.

Wijana, I. D. P. dan M. R. (2017). Semantik
Teori dan Analisis. Surakarta: Yuma Pustaka.

Zollner, N. (1997). Der Euphemismus im Altaglichen un Politischen Sparachgebraunch des Englichen. Frankfurt: Main peter lang. 